\title{
Book Review: Re-membering the Black Atlantic: on the Poetics and Politics of Literary Memory by Lars Eckstein (2006)
}

\author{
Ahmed Seif Eddine Nefnouf \\ PhD Candidate \\ Literary Studies/ Szeged University \\ Szeged, Hungary. \\ ahmednefnouf@gmail.com
}

Eckstein (2006) notes that the Atlantic slave trade has continuously haunted the cultural memories of Europe, Africa, and America. In fact, everyone wishes to forget about it. Many of the victims of the African origin tried to run away from the sites that they got traumatized, while those who were enlightened especially, the Westerners preferred to remain unconscious to these upsetting complicity between slavery and enlightenment. In the last few years, many fiction writers have made a decision to venture in re-membering the Black Atlantic.

Keywords - African, Re-Membering, Cultural Memories

The main focus of this book is to show how literature performed as a memory. It tries to showclearly how memoryand literature cross each other and offers the readers three influential novels that talk about Black Atlantic. Infact, it sets out to show that the connection between memoriesis not just that simple. The literature not only aims at sustaining or challenging the social nature of memory in several ways by subverting or even preserving the cultural meanings, or even by dispersing and commenting about it. Eckstein (2006) further 
notes that literaturemust be remembered or viewed as a very special form of what he refers to as cultural memory with its own strategies of making observations and writing based on the older memories.

The book is divided into two crucial parts. The first part of this book provides the foundation that is necessary to maintain the thesis developed in the second part of the book, which focuses on the three mnemonic fiction stories of the Black Atlantic. It is worth noting that the author acknowledge the importance of reviewing previous approaches to literature and memory when going towards 'poetics of mnemonic strategy' in writing. The author conducts the structures of the mnemonic into simple steps. Testimonies are discussedin order to understand the relationship between memory and history, although it is known to be a very problematic category. The author further discusses about the musical and visual resources where he organizes various forms and the appearances of intermedial and intertextual references that occur in narrative fictions.

The second part of the book conducts a very illustrative discussion of three literature and outlines their specific mnemonic procedures and strategies. All the readings have a particular poetic strategy that they use to access both the past and the present memories. In this case, a novelist may decide to write memories about images, texts or music. Caryl Phillips's Cambridge, for instance, collects several fragments of various slave narratives, histories, and travelogues to try and shape a brilliant montage of some of thetexts that wereforgotten. Most of his materials were from the 18th and 19th century. David Dabydeen in his book titled A Harlot's Progresstries to approach the Black Atlantic slavery through paintings by well known artists such as William Hogarth, Sir Joshua Reynolds, and J. M. W. Turner. The last novel is Beloved by Toni Morrison, focused on the black music, from the spiritual music and the blues to the John Coltrane art. The novel Beloved by Toni Morrison presented in a way that past and present show the memory and Rememory. As an example of 
that; is the presence of beloved as a ghost who is Sethe's daughter in the present. Morrison makes the novel moves between past and present; from the attitudes of the characters through remembering the past. So, Morrison here used such a type of writing which makes readers, me as well, hard to understand the novel at first, the type is storytelling which makes the readers and even characters understand the past memories

The author discuss the horrors of the Black Atlantic by claiming that is not only unique but also effective. The author first creates a theoretical framework of the book that he uses to support his arguments in the other part of the books. He uses three novels written by well known authors in the history which increases the credibility of his work. It is true that even though the novels used had different poetic approaches they were all able to represent the author's objectives: promote a sense transcultural responsibility, and the need to preserve the identity of the black society.

Remembering the Black Atlantic will bevery important in my project concerning race and slavery representation. The book contains one of the novels that will be essential in understanding the way race and slavery is represented. 


\section{Work Cited}

Eckstein, Lars. Re-Membering the Black Atlantic: on the Poetics and Politics of Literary Memory. Rodopi, 2006. 